Review Article

\title{
Forensic Science Interventions in Wildlife Mediated Zoonotic Outbreaks: A Systematic Review
}

\author{
Aby Joseph', Malini Mittal Bishnoi ${ }^{2}$ \\ ${ }^{1,2}$ Amity University, Dubai. \\ DOI: https://doi.org/10.24321/0019.5138.202046
}

\section{I $\quad \mathbf{N} \quad \mathbf{F} \quad \mathbf{O}$}

\section{Corresponding Author:}

Aby Joseph, Amity University, Dubai.

E-mail Id:

abyjsph@gmail.com

Orcid Id:

https://orcid.org/0000-0003-1395-4308

How to cite this article:

Joseph A, Bishnoi MM. Forensic Science Interventions in Wildlife Mediated Zoonotic Outbreaks: A Systematic Review. J Commun Dis 2020; 52(4): 88-96.

Date of Submission: 2020-12-02

Date of Acceptance: 2020-12-23

\author{
$\begin{array}{llllllll}\mathbf{A} & \mathbf{B} & \mathbf{S} & \mathbf{T} & \mathbf{R} & \mathbf{A} & \mathbf{C} & \mathbf{T}\end{array}$
}

\begin{abstract}
Millions of people are suffering from the repeated emergence of zoonotic diseases across the globe. The latest pandemic of Covid-19 suspected to be originated from wild animals and was transmitted via an intermediate animal host to humans. Possibilities of the intentional use of zoonoses as bioweapons cannot be ignored and it poses a threat to global biosafety and biosecurity. This review discusses the nature and types of zoonotic diseases and the link to human activities of wildlife poaching and trafficking. It is estimated that about billions of currencies are spent by nations annually due to these diseases and millions of people die as a consequence of zoonotic diseases. In this article, we reviewed on the past and present zoonotic diseases and transmission through natural, accidental and deliberate modes. This review addresses the impact of human vs. wild life conflict in emerging zoonotic diseases and focusing on bioterrorism activities. The objective of the present review was to highlight the significance of advanced forensic science technologies for the detection and prevention of the future zoonotic outbreaks of the suspected bio crimes and wildlife crimes.
\end{abstract}

Keywords: Covid-19, Epidemiology, Zoonotic diseases, Wildlife, Forensics

\section{Introduction}

Zoonosis is an infectious disease that can be transmitted from animals to humans with or without vectors, resulting in high morbidity and mortality rates. ${ }^{1,2}$ Every year, millions of deaths occur because of zoonotic transmission. Global zoonotic disease transmission adversely affects public health and the global economy. ${ }^{4,3}$ The emergence of a new zoonotic disease is unpredictable; therefore, investigation at the sign of the first emergence is crucial. Factors that may lead to new zoonotic diseases are mutation, natural selection, evolutionary progression, ecological and climatic changes, etc. ${ }^{5}$ Along with the intensification of wildlife trade have caused alterations in native habitats and forced animals to live proximate to human habitations.

The latest zoonotic pandemic, Corona Virus Disease 2019 (COVID-19), is believed to be related to a human-animal interface. Covid-19, declared a pandemic on 30 January 2020, spread to over 216 countries and territories. The disease causative agent was established as a member of the coronaviridae family, which was named by the WHO as "2019-novel coronavirus (2019-nCoV)" and was referred to as COVID-19. Later, the International Virus Taxonomy Committee (ICTV) called this new virus "SARS-CoV-2". ${ }^{3}$ Coronaviruses are positive RNA viruses, have a wide variety 
of animal hosts; they can cross the species barrier. Instability of replicase enzyme, RNA-dependent RNA polymerase, poly-basic furin cleavage site and O-linked glycan's, lack of proofreading mechanism, a higher rate of spike gene RBD mutations, and genetic recombination are the key reasons behind the emergence of new CoVs and their wide host range. ${ }^{3,6,7}$ HKU1, NL63, OC43, 229E, SARS-CoV, SARS-CoV-2, MERS-CoV are seven coronaviruses that infect humans.

\section{Methods}

\section{Eligibility and Exclusion Criteria for the Literature Search}

This systematic analysis omitted non-zoonotic microbial diseases. Scholarly work was collected from five databases until September 15, 2020, including Google Scholar, Scopus, Web of Science and Science Direct. Microbial diseases other than zoonotic were excluded from this systematic review. This analysis included original studies, review papers, and case reports.

\section{Data Screening}

Related full-text papers were accessed on databases applying microbial disease exclusion criteria other than zoonotic. The abstracts of the articles sorted were read to assess their relevance to the purpose of the current research focusing on anthropogenic exploitation as the causative factor for the emergence and re-emergence of new zoonotic diseases, various aspects of animal reservoirs of zoonotic diseases, and role of forensics in prevention measures and possible research. If found apt, the introduction and/ or results sections were further scrutinized to ensure that the sorted articles met the exclusion criteria and the purpose of the research. Those articles that did not relate directly to zoonotic diseases, thereby not meeting the eligibility criteria and purpose of the present study were expressly excluded.

\section{Result and Discussion}

Zoonotic outbreaks may occur either naturally or by deliberate acts of bioterrorism or bio crimes. ${ }^{8,9,10}$ Efficient animal and human surveillance are crucial steps towards early detection and potential prediction of new infectious zoonotic diseases. ${ }^{5}$ When zoonotic diseases begin to appear unknown, human and animal authorities are needed to identify, monitor and prevent emergencies of public health. ${ }^{11,12}$ Surveillance of pathogens harbouring wildlife species and regions are important to detect and avoid possible future pandemics. ${ }^{13,15}$

\section{Animals: Zoonotic Reservoirs}

New pathogenic zoonotic diseases conquer a hierarchical set of barriers to adapt effectively to fluctuating environments. ${ }^{15,16}$ Both domestic animals and wildlife can be the primary hosts of zoonotic diseases. ${ }^{3}$ Animal-based food intake raises the risk of zoonotic disease transmission. ${ }^{17,18}$ Retroviruses including Simian Immunodeficiency Virus (SIV), Simian T-lymphotropic Virus (STLV) and Simian Foam Virus (SFV) are transmitted to humans through captive harvesting of Non-Human Primates (NHP), bushmeat, and NHP exposure. ${ }^{19,20,21}$

Bats are flight mammals and act as excellent virus reservoirs since viruses survive asymptomatically in bats. ${ }^{22}$ Bats are eaten as food in many countries. ${ }^{23,24}$ Bats have a migratory capacity, which increases the possibility of disease transmission. Viruses arising from bats and presenting a threat to human health include bat lyssaviruses, CoVs, Henipa viruses and filoviruses. ${ }^{15}$ Transmissions of the batto-human disease can occur directly or indirectly. Direct transmission can occur through interaction with infected bat or can occur through intermediate hosts such as civet cats, camel, etc. ${ }^{25,26}$ Hindra viral attack and nipah viral spread show that environment sharing with bats promotes disease transmission. Hindra viral attack in East Australia was transmitted from horses, serving as primary hosts for bats in the same area. Similarly, pigs were the intermediate host of Nipah viral spread in Malaysia, a viral spillover from bats. ${ }^{27}$

SARS-CoV and MERS-CoV were transmitted by bats and caused high mortality outbreak in 2003 and 2012, respectively. ${ }^{3}$ SARS-CoV in China, originating from bats, entered humans via masked civets, serving as intermediate hosts. MERS, the coronaviruses in Saudi Arabia spread from bats and the virus entered humans via the camel, serving as an intermediate host. Consumption of raw milk and camel meat and contaminated camel exposure allowed transmission to humans. Bats are the main source of COVID-19 zoonotic spill-over, as SARS-CoV-2 reveals 96 per cent of genome-level bat CoV. A suspected intermediate animal host pangolin may have transmitted SARS-CoV- 2 to humans. Pangolins are nocturnal, insect-eating rodents, the world's most trafficked species for food and traditional medicine. ${ }^{25,28,29}$ Increased demand for pangolins leads to illicit trade and over-exploitation of pangolins may lead to its extinction. ${ }^{30}$ Pangolin's different parts (scales, bone, head and meat) are used for various purposes including spiritual protection, rheumatism, infertility, seizures, food, skin diseases, and digestive problems. Pangolins are the natural hosts of beta coronavirus, genetically linked to bat coronavirus. ${ }^{31,32,33,23,24,34}$

Lymphocytic choriomeningitis and rat-bite fever are serious zoonotic diseases found worldwide. ${ }^{35}$ Several wildlife zoonoses are transmitted by insect mosquitoes, such as Rift valley fever, equine encephalitis, and Japanese encephalitis. Zoonotic agents can also be transmitted by consuming meat from infected carcasses or drinking polluted water. ${ }^{13}$ Rabies virus is primarily transmitted through dog bites and 
high-risk infections of Bartonella hensla and Pasteurella multocida occur by cat bite and scratches. ${ }^{2,36}$ Pet birds are possible carriers of human-impacted zoonotic diseases such as chlamydophilosis (parrot fever), campylobacteriosis and salmonellosis. ${ }^{2,37}$ Transmission of horse zoonoses involves oral, inhalation, and skin contact, often causing human and equine death. ${ }^{38}$ Some major life-threatening zoonotic diseases and epidemiology are mentioned in Table 1.

Table I.Description of some of the potential zoonotic outbreaks and its epidemiology ${ }^{76}$

\begin{tabular}{|c|c|c|c|c|c|c|c|}
\hline No. & Disease & Pathogen & Animal host & $\begin{array}{l}\text { Mode of } \\
\text { transmission }\end{array}$ & $\begin{array}{c}\text { Year of } \\
\text { emergence } \\
\text { and origin } \\
\text { of country }\end{array}$ & Symptoms & $\begin{array}{l}\text { Fatality } \\
\text { rate }\end{array}$ \\
\hline 1. & Influenza & $\begin{array}{c}\text { Influenza A } \\
\text { virus }\end{array}$ & $\begin{array}{l}\text { Horses, pigs, } \\
\text { domestic and } \\
\text { wild birds, } \\
\text { wild aquatic } \\
\text { mammals } \\
\text { and farmed } \\
\text { carnivores }\end{array}$ & $\begin{array}{l}\text { Droplets } \\
\text { transmitted } \\
\text { through air }\end{array}$ & 1918, Italy & $\begin{array}{l}\text { fever, runny } \\
\text { nose, sore } \\
\text { throat, muscle } \\
\text { and joint pain, } \\
\text { headache, } \\
\text { coughing, and } \\
\text { feeling tired }\end{array}$ & \\
\hline 2. & $\begin{array}{l}\text { Crimean- } \\
\text { Congo } \\
\text { hemor- } \\
\text { rhagic fever }\end{array}$ & $\begin{array}{c}\text { Crimean-Congo } \\
\text { haemorrhagic } \\
\text { fever } \\
\text { orthonairovirus }\end{array}$ & $\begin{array}{l}\text { Cattle, goat, } \\
\text { sheep, rat, } \\
\text { birds }\end{array}$ & $\begin{array}{l}\text { Tick bites, contact } \\
\text { with body fluids }\end{array}$ & 1944, Africa & $\begin{array}{l}\text { fever, muscle } \\
\text { ache, dizziness, } \\
\text { neck pain, } \\
\text { backache, } \\
\text { headache, } \\
\text { sore eyes and } \\
\text { photophobia }\end{array}$ & $10-40 \%$ \\
\hline 3. & $\begin{array}{l}\text { Ebola virus } \\
\text { disease } \\
\text { (EVD) }\end{array}$ & $\begin{array}{l}\text { Ebola virus } \\
\text { species }\end{array}$ & $\begin{array}{l}\text { fruit bats, } \\
\text { porcupines } \\
\text { and non- } \\
\text { human } \\
\text { primates }\end{array}$ & $\begin{array}{l}\text { direct contact } \\
\text { with the blood, } \\
\text { secretions, organs } \\
\text { or other bodily } \\
\text { fluids of infected } \\
\text { people }\end{array}$ & $\begin{array}{c}1976, \\
\text { central } \\
\text { Africa }\end{array}$ & $\begin{array}{l}\text { fever, fatigue, } \\
\text { muscle, pain, } \\
\text { headache, and } \\
\text { sore throat }\end{array}$ & $25-90 \%$ \\
\hline 4. & $\begin{array}{c}\text { Hendra } \\
\text { virus (HeV) } \\
\text { infection }\end{array}$ & Hendra virus & $\begin{array}{l}\text { Bat and } \\
\text { horses }\end{array}$ & $\begin{array}{l}\text { respiratory } \\
\text { secretions, blood } \\
\text { or other body } \\
\text { fluids }\end{array}$ & $\begin{array}{c}\text { 1994, } \\
\text { Australia }\end{array}$ & $\begin{array}{l}\text { mild influenza- } \\
\text { like illness to } \\
\text { fatal respiratory } \\
\text { or neurological } \\
\text { disease } \\
\end{array}$ & $70 \%$ \\
\hline 5. & Lassa fever & $\begin{array}{l}\text { Lassa fever } \\
\text { virus }\end{array}$ & rodents & $\begin{array}{c}\text { exposure to food } \\
\text { or household items } \\
\text { contaminated with } \\
\text { urine or faeces of } \\
\text { infected Mastomys } \\
\text { rats }\end{array}$ & $\begin{array}{l}\text { 1969, } \\
\text { Nigeria }\end{array}$ & $\begin{array}{c}\text { fever, general } \\
\text { weakness and } \\
\text { malaise }\end{array}$ & $15 \%$ \\
\hline 6. & $\begin{array}{l}\text { Marburg } \\
\text { virus } \\
\text { disease }\end{array}$ & Marburg virus & $\begin{array}{c}\text { Rousettus } \\
\text { bat }\end{array}$ & $\begin{array}{l}\text { blood, secretions, } \\
\text { organs or other } \\
\text { bodily fluids of } \\
\text { infected people, } \\
\text { and with surfaces } \\
\text { and materials } \\
\text { contaminated with } \\
\text { these fluids }\end{array}$ & $\begin{array}{c}\text { 1967, } \\
\text { Germany } \\
\text { and Serbia }\end{array}$ & $\begin{array}{l}\text { high fever, } \\
\text { severe } \\
\text { headache and } \\
\text { severe malaise } \\
\text { Muscle aches }\end{array}$ & $88 \%$ \\
\hline
\end{tabular}




\begin{tabular}{|c|c|c|c|c|c|c|c|}
\hline 7. & $\begin{array}{c}\text { Middle East } \\
\text { respiratory } \\
\text { syndrome } \\
\end{array}$ & $\begin{array}{c}\text { MERS } \\
\text { coronavirus }\end{array}$ & $\begin{array}{c}\text { Bats and } \\
\text { camel }\end{array}$ & Close contact & $\begin{array}{l}\text { 2012, Saudi } \\
\text { Arabia }\end{array}$ & $\begin{array}{l}\text { fever, cough } \\
\text { and shortness } \\
\text { of breath }\end{array}$ & $34.4 \%$ \\
\hline 8. & $\begin{array}{l}\text { Monkey pox } \\
\text { virus }\end{array}$ & $\begin{array}{l}\text { Monkey pox } \\
\text { virus }\end{array}$ & $\begin{array}{l}\text { Gambian } \\
\text { poached rats, } \\
\text { dormice, } \\
\text { different } \\
\text { species of } \\
\text { monkeys }\end{array}$ & $\begin{array}{l}\text { bodily fluids, } \\
\text { lesions on the } \\
\text { skin or on internal } \\
\text { mucosal surfaces, } \\
\text { such as in the } \\
\text { mouth or throat, } \\
\text { respiratory } \\
\text { droplets and } \\
\text { contaminated } \\
\text { objects }\end{array}$ & $\begin{array}{l}\text { 1970, } \\
\text { central and } \\
\text { western } \\
\text { Africa }\end{array}$ & $\begin{array}{l}\text { fever, cough, } \\
\text { severe } \\
\text { headache }\end{array}$ & $1-15 \%$ \\
\hline 9. & $\begin{array}{l}\text { Nipah virus } \\
\text { infection }\end{array}$ & Nipah virus & Bats and pigs & $\begin{array}{l}\text { contaminated } \\
\text { food or directly } \\
\text { between people }\end{array}$ & $\begin{array}{c}\text { 1999, } \\
\text { Malaysia }\end{array}$ & $\begin{array}{c}\text { acute } \\
\text { respiratory } \\
\text { illness and fatal } \\
\text { encephalitis }\end{array}$ & $40-75 \%$ \\
\hline 10. & COVID-19 & SARS-CoV-2 & $\begin{array}{l}\text { Suspected: } \\
\text { Bats and } \\
\text { pangolins }\end{array}$ & $\begin{array}{l}\text { small droplets } \\
\text { from the nose or } \\
\text { mouth }\end{array}$ & 2019, China & $\begin{array}{l}\text { Fever, } \\
\text { throat pain, } \\
\text { respiratory } \\
\text { problems }\end{array}$ & \\
\hline 11. & Plague & $\begin{array}{c}\text { Yersinia pestis } \\
\text { bacteria }\end{array}$ & $\begin{array}{c}\text { small } \\
\text { mammals } \\
\text { and their } \\
\text { fleas }\end{array}$ & $\begin{array}{l}\text { bite of infected } \\
\text { fleas, through } \\
\text { direct contact with } \\
\text { infected materials, } \\
\text { or by inhalation }\end{array}$ & 1990, Africa & $\begin{array}{l}\text { fever, chills, } \\
\text { aches, } \\
\text { weakness, } \\
\text { vomiting and } \\
\text { nausea }\end{array}$ & $30-60 \%$ \\
\hline 12. & $\begin{array}{l}\text { Rift Valley } \\
\text { fever (RVF) }\end{array}$ & Phlebovirus & $\begin{array}{l}\text { Rats and } \\
\text { mice }\end{array}$ & $\begin{array}{l}\text { Bites of rats, } \\
\text { urine and mucus } \\
\text { secretions }\end{array}$ & 1931, Kenya & $\begin{array}{c}\text { flu-like fever, } \\
\text { muscle pain, } \\
\text { joint pain and } \\
\text { headache }\end{array}$ & $>1 \%$ \\
\hline
\end{tabular}

The table above indicates that viruses are the main agents transmitting zoonosis. Viruses contain no genetic code set and cannot reproduce alone. They infect the host cell for replication and rapidly mutate. ${ }^{39}$ Studies of zoonotic virus emergence and its dissemination are incomplete. Bacteria are another agent transmitting disease. Antibiotics help minimize the risk of bacterial zoonotic outbreaks, though antibiotic resistance remains a major global concern. ${ }^{40,41}$ Parasitic worms like Helminths and obligatory intracellular parasites like protozoans are another group of dreadful disease-causing agents. ${ }^{42,43}$ Urbanization, agricultural conversion, deforestation and habitat degradation have led to an increase in the emergence and spread of such new pathogens. ${ }^{35}$

\section{Anthropogenic Activity: Zoonoses}

Wildlife activity threatens human health by transmitting infectious diseases to humans. ${ }^{13}$ Overall, $60 \%$ of emerging infectious diseases are zoonotic, $75 \%$ of which emerged in animals: 30 new human pathogens have been identified in the last three decades ${ }^{44}$ Wildlife zoonoses represent broad transmission range. For example, Francisella turarensis is transmitted by skin contact with infected or dead mice and rodent to human Hantavirus transmission occurs by rodent excreta aerosols in the dust. ${ }^{13}$

Wet markets are used to trade wildlife animals like palm civets, ferrite badgers, barking deer, wild boars, hedgehogs, foxes, squirrels, bamboo rats, gerbils, different types of snacks and even domestic dogs, cats, rabbits. ${ }^{19,3}$ The live animal market encourages inter-species communication, which enhances the transmission of zoonotic infectious diseases. Wildlife trade survey found that a single market in northern Sulawesi, Indonesia, sold up to 90,000 mammals per year. Similarly, Thailand's single market sold 276 bird species (> 70,000) for 25 weekends. Like above, Bangkok sold 36,537 birds from 4 markets. Annual wildlife consumption in Central Africa is approximately one billion kilograms per year, while in the Amazon Basin it ranges from 67 to 164 million kilograms. Tens of millions of wild animals are transported from East and Southeast Asia. ${ }^{6,7,46,23,24}$ Huge wildlife and wildlife imports are allowed in the United 
States. Approximately 1.2 billion live wildlife and 25 million kilograms of -live wildlife are transported annually in the US. ${ }^{47,19}$ Permanent wildlife trade ban is no solution, as it is likely to increase illicit wildlife trade. ${ }^{3}$

Trade of wildlife and consumption in Asian countries is excessive. ${ }^{27,48}$ Hunting, selling, and bushmeat butchering encourage new zoonotic diseases. Wildlife farms have emerged in China for growing wildlife from peacocks to civets, food and medicine. ${ }^{49,50}$ These animals are restricted to small spaces in close and regular physical contact with humans, where pathogens can easily spread. ${ }^{51}$ The popularity of traditional Chinese medicines also leads to legal and illegal wildlife trade. ${ }^{25}$

\section{Zoonotic Agents: Bio Crime and Bioterrorism}

Zoonotic pathogens are used as bioweapons to commit acts bioterrorism and bio crimes, causing death or crippling diseases; most of them are aerosolized and can be spread in large areas. ${ }^{60}$ Centre for Disease Control and Prevention (CDC) classifies bioterrorism agents into three classes: Types A, B and C. Class A pathogens are priority bioterrorism agents, $80 \%$ of which are zoonoses. ${ }^{62}$ Smallpox is the only disease in the 'Class $A$ list of $C D C^{\prime}$ ' that is now ineffective due to active worldwide vaccination campaigns in the late 1970s. Common zoonotic agents used in bio-warfare programs include anthrax bacteria, plaque, brucellosis, cryptosporidiosis, Q-fever, viral equine encephalitis, etc. Aerosol sprays are one of the most possible bioterrorism methods, as they quickly spread and infiltrate bronchioles and alveoli. ${ }^{63}$ Table 2, indicates the Type A pathogens defined by the Centre for Disease Control and Prevention.
The key reasons behind the use of zoonotic agents as bioweapons include (1) high morbidity and lethality (2) highly infectious or toxic (3) capable of mass production and storage before distribution without loss of pathogenic efficiency (4) ideal for long-term environmental sustainability after transmission (5) and (6) capable of genetic engineering and weapons. Advancing life science technologies promote the production of state-run biological weapons. The United States of America and the Soviet Union have produced various bioweapons to kill or incapacitate humans and destroy crops and livestock through government-sponsored biological warfare. Recent advances in molecular biology and genetic engineering have allowed genetically modified zoonotic agents to be produced, which are more virulent and difficult to control upon outbreak. ${ }^{68}$ Some extremist groups may have experience with such technologies, resulting in substantial global danger. ${ }^{67}$ Technological developments, however, also improve our ability to investigate an event and locate the cause.

During World War II, japan used enemy zoonotic bioweapons. ${ }^{71}$ The U.S. military built a bioweapon arsenal capable of triggering deadly zoonotic diseases such as Anthrax, Bucellosis, Q fever, Tularemia and Equine Encephalitis. Other human-made outbreaks of zoonotic diseases are the spread of plague-contaminated fleas by Japanese troops in Manchuria and China, supplying blankets from smallpox victims to Native American Indians, catapulting manure using bodies of dead plague victims or cattle into besieged cities. ${ }^{65,66}$ In 1972, 170 nations signed the Biological and Toxin Weapon Convention to ban the use of biological agents in warfare. ${ }^{10}$

Table 2.CDC category A high sequence of pathogens and toxins ${ }^{77}$

\begin{tabular}{|c|c|c|c|}
\hline Disease & Pathogen & Incubation period & Mortality \\
\hline Anthrax & Bacillus anthracis & $1-6$ days & $\begin{array}{c}20 \% \text { for cutaneous anthrax, } \\
25-75 \% \text { for gastrointestinal } \\
\text { anthrax, 80\% Or higher for } \\
\text { inhalation anthrax }\end{array}$ \\
\hline Botulism & Clostridium botulinum toxin & 2 hour to 10 Days & $5-10 \%$ \\
\hline Plague & Yersinia pestis & $1-6$ days & $30-60 \%$ \\
\hline Smallpox & variola major & $4-19$ days & $\begin{array}{c}3 \% \text { if vaccinated, } 30 \% \text { if } \\
\text { unvaccinated }\end{array}$ \\
\hline Tularemia & Francisella tularensis & $1-25$ days & $\begin{array}{c}4-50 \% \text { without treatment, } 1 \% \\
\text { with treatment }\end{array}$ \\
\hline $\begin{array}{c}\text { Filoviruses haemorrhagic } \\
\text { fevers }\end{array}$ & Ebola virus & $2-21$ days & $25-90 \%$ \\
\cline { 2 - 4 } & Marburg virus & $2-21$ days & $24-88 \%$ \\
\hline $\begin{array}{c}\text { Arenaviruses hemorrhagic } \\
\text { fevers }\end{array}$ & Lassa virus & $6-21$ days & $1 \%$ \\
\cline { 2 - 4 } & Machupo virus & $1-2$ weeks & $25-35 \%$ \\
\hline
\end{tabular}


Zoonotic agent-driven bioterrorism adversely affects our biodiversity, endangering different species populations. ${ }^{68,69}$ Factors contributing to the extinction of endangered and threatened species include relatively small population size, inbreeding depression, and exotic disease organism exposure. ${ }^{73}$ Most recent bioweapons are wide-spectrum zoonotic diseases that can cause high mortality and morbidity in various animal species as well as humans. ${ }^{70,71}$ West Nile Virus (WNV) emergence in North America in 1999 is the possible example of bioweapon disease dispersal capabilities. WNV-transmitted mosquito dispersion is difficult to detect and monitor and can be lethal to humans, birds and mammals. ${ }^{68,72}$ Canine distemper, a viral disease of domesticated dogs, was grown and tested in bioweapon laboratories making it vulnerable to wild carnivores. Decline and disappearance of black-footed ferrets in North America's Great Plain area were caused by canine distemper effects. Control programs culminated in wildlife eradication. Rabies prevention systems suggest adverse effects on non-target animals including red fox, jackals, and raccoons. ${ }^{74}$ Improved interagency and intergovernmental coordination, cooperation, and partnership mechanisms are required to address the threat of outbreaks of bioweapon disease. Failure to arrest this hazard poses several hazards, including erosion.

\section{Role of Forensic Investigation in Zoonosis Outbreaks}

Forensic science plays a special role in bioterrorism investigations from the crime scene to court. ${ }^{55}$ Like epidemiological research, forensic investigations may distinguish between natural, unintended, or purposeful causes of a pathogenic outbreak. One example of zoonotic bioterrorism is 'Anthrax Letters' in the USA in 2001, resulting in fewer deaths and decreased disease spread. A successful forensic analysis method from sample collection to interpretation was performed and the findings concluded that a top defence researcher Bruce Ivins was the source of spores in Anthrax letter ${ }^{55}$ in government biodefense laboratories.

Microbial forensics is an emerging forensic science scientific discipline that connects microbiology and forensics dedicated to analysing evidence from bioterrorism, bio crime, and hoaxes. ${ }^{53}$ Microbial forensic organisations have started to set up research teams explicitly to investigate forensics of infectious outbreaks, Anthrax outbreak control was one such milestone in microbial forensics. ${ }^{52}$ Success stories of microbial forensic investigations include identifying the source of HIV transmission in Florida by sequencing PCRamplified viral genes, and equally daunting research into the sudden outbreak of West Nile Virus in the northern US in 1999 identified a dead goose in Israel as the source of virus. ${ }^{56}$ Many forensic science labs still lack biosafety level 3 or 4 containment facilities, and forensic scientists are not qualified in microbiology practices to handle dangerous pathogens. A collaborative program with well-equipped microbiology labs and forensic science expertise can be an excellent forum for such research. Establishing an appropriate forensic method will go a long way in improving bioweapon protection. ${ }^{8}$ Advanced technologies of IT in the illicit production and procurement of hazardous materials in a supply chain management can be effectively utilized for bio threats. 82 Cities becoming smarter, providing digital forensics with real-time information sources, with the aid of Al, data collected can be used to track the illegal activities of bio-research facilities. ${ }^{78}$ Centralized RFID and IOT sensor-based bioresearch specimen tracking devices and consumables connected with national security systems. ${ }^{79}$ $\mathrm{Al}$ and Big data can be used to solve environmental threats associated with illegal wildlife trafficking, in particular geography. ${ }^{80}$

Several advanced molecular techniques including molecular phylogeny, whole-genome sequencing, microarray analysis and DNA sequencing are used in microbial forensic investigations to distinguish molecular differences between microbial strains. Microarray research plays a crucial role in microbial forensics and is used to study community composition, species development, and virulence acquisition. In forensic studies, applying molecular biomarkers can lead to important revelations. With molecular techniques, MALDI-TOF uses lipid profiling and complete proteome analysis to identify molecular signature. ${ }^{68}$ MALDI-TOF is the matrix-assisted laser disruption ionization-time of flight-mass spectroscopy used to get fast results from the sample regarding biomarker recognition, subtyping and direct detection. Two main molecular biology techniques used in forensic investigations are Polymerase Chain Reaction (RT-PCR) and PCR (rep-PCR) repetitive components. RT-PCR provides high throughput, sensitivity, specificity and resolution while rep-PCR is less widely used but more general in application, useful in characterizing evidence when genomic signatures are not clear. ${ }^{75}$ Advances in microbial forensics are crucial to pursuing bio-criminal security. Global alliances and political decisions play a key role in effective control systems. ${ }^{8}$

\section{Conclusion}

The review discusses the various natural, accidental and deliberate zoonotic diseases and its impact of the global health, and economy were discussed in the contest bioterrorism. Advanced digital and microbial forensic technologies lend promise to the future of disease surveillance and detection of zoonotic outbreaks linked with bio crimes. Additionally, rapid point-of-care diagnostic tests for zoonotic infections can be useful during wildlife investigations. Accessibility of these tests to a forensic expert can aid in the rapid diagnosis of existing 
and emerging infectious diseases of the wildlife animals and parts. Collaborative approaches of public health, animal health, forensic science and molecular biology and information technology can effectively use for the ground-level surveillance of confiscated wildlife products and parts involve investigation of wildlife crimes. Chain of custody, collection of evidence, adequate planning, public health surveillance and communication between health practitioners and the general public is therefore important for the prevention and control of disease outbreaks.

\section{Conflicts of Interest: None}

\section{References}

1. Belay ED, Kile JC, Hall AJ et al. Zoonotic disease programs for enhancing global health security. Emerging Infectious Diseases 2017; 23(Suppl 1): S65.

2. Cantas L, Suer K. Review: The important bacterial zoonoses in "one health" concept. Frontiers in Public Health 2014; 2: 144.

3. Tiwari R, Dhama K, Sharun K et al. COVID-19: animals, veterinary and zoonotic links. Veterinary Quarterly 2020.

4. Ayittey FK, Ayittey MK, Chiwero NB et al. Economic impacts of Wuhan 2019-nCoV on China and the world. Journal of Medical Virology 2020; 92(5): 473-5.

5. Murphy FA. Emerging zoonoses. Emerging Infectious Diseases 1998; 4(3): 429.

6. Su S, Wong G, Shi W et al. Epidemiology, genetic recombination, and pathogenesis of coronaviruses. Trends in Microbiology 2016; 24(6): 490-502.

7. Chen J. Pathogenicity and transmissibility of 2019nCoV - a quick overview and comparison with other emerging viruses. Microbes and Infection 2020.

8. Serrano I, Gomes D, Ramilo D et al. An overview of zoonotic disease outbreaks and its forensic management over time. Journal of Forensic Sciences 2019; 64(5): 1304-1311.

9. Geneva: World Health Organization (WHO). World Health Organization and Global Partnership to Roll Back Malaria. Using climate to predict infectious disease outbreaks: a review 2004.

10. Jansen HJ, Breeveld FJ, Stijnis C et al. Biological warfare, bioterrorism, and biocrime. Clinical Microbiology and Infection 2014; 20(6): 488-496.

11. Shiferaw ML, Doty JB, Maghlakelidze G et al. Frameworks for preventing, detecting, and controlling zoonotic diseases. Emerging infectious diseases 2017; 23(Suppl 1): S71.

12. Furuse $Y$, Suzuki A, Oshitani H. Origin of measles virus: divergence from rinderpest virus between the 11th and 12 th centuries. Virology journal 2010; 7(1): 1-4.

13. Kruse H, Kirkemo AM, Handeland K. Wildlife as source of zoonotic infections. Emerging infectious diseases
2004; 10(12): 2067.

14. Wang LF, Cowled C. (Eds.) Bats and viruses: a new frontier of emerging infectious diseases. John Wiley \& Sons 2015.

15. Plowright RK, Parrish CR, McCallum H et al. Pathways to zoonotic spillover. Nature Reviews Microbiology 2017; 15(8): 502-510.

16. Regoes RR, Hamblin S, \& Tanaka MM et al. Viral mutation rates: modelling the roles of within-host viral dynamics and the trade-off between replication fidelity and speed. Proceedings of the Royal Society B: Biological Sciences 2013; 280(1750): 2012-2047.

17. Rajala EL, Sattorov N, Boqvist S et al. Bovine leptospirosis in urban and peri-urban dairy farming in low-income countries: a "One Health" issue? Acta veterinaria scandinavica 2017; 59 (1): 1-4.

18. Ducrotoy MJ, Bertu WJ, Ocholi RA et al. Brucellosis as an emerging threat in developing economies: lessons from Nigeria. PLoS Negl Trop Dis 2014; 8(7): 3008.

19. Smith KM, Anthony SJ, Switzer WM et al. Zoonotic viruses associated with illegally imported wildlife products. PloS one 2012; 7(1): 29-505.

20. Switzer WM, Heneine W. Foamy virus infection of humans. Molecular detection of human viral pathogens 2011; 1:31-46.

21. Courgnaud V, Van Dooren S, Liegeois F et al. Simian T-cell leukaemia virus (STLV) infection in wild primate populations in Cameroon: evidence for dual STLV type 1 and type 3 infection in agile mangabeys (Cercocebus agilis). Journal of virology 2004; 78(9): 4700-4709.

22. Fan Y, Zhao K, Shi ZL et al. Bat coronaviruses in China. Viruses 2019; 11(3):210.

23. Tang XC, Zhang JX, Zhang SY et al. Prevalence and genetic diversity of coronaviruses in bats from China. Journal of virology 2006; 80(15): 7481-7490.

24. Rodriguez-Morales AJ, Bonilla-Aldana DK, Balbin-Ramon $\mathrm{G} J$ et al. History is repeating itself: Probable zoonotic spillover as the cause of the 2019 novel Coronavirus Epidemic. Infez Med 2020; 28(1): 3-5.

25. Volpato G, Fontefrancesco M. F, Gruppuso P, et al. Baby pangolins on my plate: possible lessons to learn from the COVID-19 pandemic 2020.

26. Li X, Zai J, Zhao Q et al. Evolutionary history, potential intermediate animal host, and cross-species analyses of SARS-CoV-2. Journal of medical virology 2020; 92(6): 602-611.

27. Pulliam JR, Epstein JH, Dushoff J et al. Agricultural intensification, priming for persistence and the emergence of Nipah virus: a lethal bat-borne zoonosis. Journal of the Royal Society Interface 2012; 9(66): 89-101.

28. Gaski AL, Johnson KA. Prescription for extinction: endangered species and patented Oriental medicines 
in trade/ Andrea L. Gaski, Kurt A. Johnson. Species in danger (USA) 1994.

29. Sodeinde OA, Adedipe SR. Pangolins in south-west Nigeria-current status and prognosis. Oryx 1994; 28(1): 43-50.

30. Challender DW.S, Hywood L. African pangolins under increased pressure from poaching and intercontinental trade. Traffic Bulletin 2012; 24(2): 53-55.

31. Andersen KG, Rambaut A, Lipkin WI et al. The proximal origin of SARS-CoV-2. Nature medicine 2020; 26(4): 450-452.

32. Boakye MK, Pietersen DW, Kotzé A et al. Knowledge and uses of African pangolins as a source of traditional medicine in Ghana. PLoS One 2015; 10(1): 117-199.

33. Boakye MK, Pietersen DW, Kotzé A et al. Ethnomedicinal use of African pangolins by traditional medical practitioners in Sierra Leone. Journal of Ethnobiology and Ethnomedicine 2014; 10 (1): 76.

34. Budowle B, Murch R, Chakraborty R. Microbial forensics: the next forensic challenge. International journal of legal medicine 2005; 119(6): 317-330.

35. White RJ, Razgour O. Emerging zoonotic diseases originating in mammals: a systematic review of effects of anthropogenic land-use change. Mammal Review 2020.

36. Mandell GL, Douglas Jr RG, Bennett JE. Principles and practice of infectious diseases. Volumes 1 and 2. John Wiley \& Sons 1979.

37. Evans EE. Zoonotic diseases of common pet birds: psittacine, passerine, and columbiform species. Veterinary Clinics: Exotic Animal Practice 2011; 14(3): 457-476.

38. Sack A, Oladunni FS, Gonchigoo B et al. Zoonotic Diseases from Horses: A Systematic Review. VectorBorne and Zoonotic Diseases 2020.

39. Duffy S, Shackelton LA, \& Holmes EC. Rates of evolutionary change in viruses: patterns and determinants. Nature Reviews Genetics 2008; 9(4): 267-276.

40. Tilman D, Cassman KG, Matson PA et al. Agricultural sustainability and intensive production practices. Nature 2002; 418(6898): 671-677.

41. Otero-Abad B, Rüegg S. R, Hegglin D et al. Mathematical modelling of Echinococcus multilocularis abundance in foxes in Zurich, Switzerland. Parasites \& vectors 2017; 10 (1): 21.

42. Thompson RA. Giardiasis as a re-emerging infectious disease and its zoonotic potential. International journal for parasitology 2000; 30 (12-13): 1259-1267.

43. Jones KE, Patel NG, Levy MA et al. Global trends in emerging infectious diseases. Nature 2008; 451 (7181): 990-993.

44. Sehgal RNM. Deforestation and avian infectious diseases. Journal of experimental biology 2010; 213(6): 955-960.

45. Ji W, Wang W, Zhao $X$ et al. Cross-species transmission of the newly identified coronavirus 2019-nCoV. Journal of medical virology 2020; 92(4): 433-440.

46. Smith KF, Behrens M, Schloegel LM et al. Reducing the risks of the wildlife trade. Science 2009; 324(5927): 594-595.

47. Golden CD, Fernald LC, Brashares JS et al.Benefits of wildlife consumption to child nutrition in a biodiversity hotspot. Proceedings of the National Academy of Sciences 2011; 108(49): 19653-19656.

48. Zhang L, Yin F. Wildlife consumption and conservation awareness in China: a long way to go. Biodiversity and Conservation 2014; 23(9): 2371-2381.

49. Guan $Y$, Zheng BJ, He YQ et al. Isolation and characterization of viruses related to the SARS coronavirus from animals in southern China. Science 2003; 302 (5643): 276-278.

50. Smit LA, Heederik D. Impacts of intensive livestock production on human health in densely populated regions. GeoHealth 2017; 1(7): 272-277.

51. Khan A. S. Public health preparedness and response in the USA since 9/11: a national health security imperative. The Lancet 2011; 378(9794): 953-956.

52. Budowle B, Murch R, Chakraborty R. Microbial forensics: the next forensic challenge. International journal of legal medicine 2005; 119(6): 317-330.

53. Pattnaik P, Jana A. M. Microbial forensics: applications in bioterrorism. Environmental Forensics 2005; 6(2): 197-204.

54. National Research Council. Review of the scientific approaches used during the FBI's investigation of the 2001 anthrax letters. National Academies Press 2011.

55. Erickson J. On the trail of a germ: Microbial forensics poised to become new anti-terror tool. Rockey Mountain News 2003.

56. McCarthy M. 26 nations join US Global Health Security Agenda. BMJ: British Medical Journal (Online) 2014; 348.

57. Rist CL, Arriola CS, Rubin C. Prioritizing zoonoses: a proposed one health tool for collaborative decisionmaking. PloS one 2014; 9(10): 109-986.

58. Bidaisee S, Macpherson CN. Zoonoses and one health: a review of the literature. Journal of parasitology research 2014.

59. Ryan CP. Zoonoses likely to be used in bioterrorism. Public health reports 2008; 123(3): 276-281.

60. World Health Organization (WHO). Public health response to biological and chemical weapons: WHO guidance, 2004.

61. Walter Reed Army Medical Center .Personal protective measures against insects and other arthropods of 
military significance 2002.

62. Robertson AG, Robertson L.J. From asps to allegations: biological warfare in history. Military medicine 1995; 160(8): 369-373.

63. Christopher LGW, Cieslak LT.J, Pavlin JA et al. Biological warfare: a historical perspective. Jama 1997; 278(5): 412-417.

64. Robertson AG, Robertson L.J. From asps to allegations: biological warfare in history. Military medicine 1995; 160(8): 369-373.

65. Martin JW, Christopher GW, Eitzen EM. History of biological weapons: from poisoned darts to intentional epidemics. Medical aspects of biological warfare 2007; 1-20.

66. Atlas RM. The medical threat of biological weapons. Critical reviews in microbiology 2008; 24 (3): 157-168.

67. Dudley JP, Woodford MH. Bioweapons, Biodiversity, and Ecocide: Potential Effects of Biological Weapons on Biological Diversity: Bioweapon disease outbreaks could cause the extinction of endangered wildlife species, the erosion of genetic diversity in domesticated plants and animals, the destruction of traditional human livelihoods, and the extirpation of indigenous cultures. Bioscience 2002; 52(7): 583-592.

68. Daszak $P$, Cunningham AA, Hyatt AD. Emerging infectious diseases of wildlife. threats to biodiversity and human health science 2000; 287(5452): 443-449.

69. Richman LK, Montali RJ, Garber RL et al. Novel endotheliotropic herpesviruses fatal for Asian and African elephants. Science 1999; 283(5405): 1171-1176.

70. Brown C. Economic considerations of agricultural diseases. Annals of the New York academy of sciences 1999; 894 (1): 92-94.

71. Rappole JH, Derrickson SR, Hubalek Z. Migratory birds and spread of West Nile virus in the Western Hemisphere. Emerging infectious diseases 2000; 6 (4): 319

72. Singer FJ, Zeigenfuss LC, Spicer L. Role of patch size, disease, and movement in rapid extinction of bighorn sheep. Conservation Biology 2001; 15(5): 1347-1354.

73. Alibek, K. Biohazard. Random House 2008.

74. Bannan PK. Role of law enforcement response and microbial forensics in investigation of bioterrorism. Croat Med J 2007; 48: 437-439.

75. World Health Organisation (WHO).Diease outbreak, 2020 https://www.who.int/emergencies/diseases/en/.

76. Centre for disease control and prevention. Bioterrorism agents/diseases, 2018. https://emergency.cdc.gov/ agent/agentlist-category.asp.

77. Chaudhry AR, Rajput B, Mishra R. Influence of IoT \& AI in place making and creating Smart Cities. International Conference on Computing, Communication and Networking Technologies (ICCCNT) 2019; 1-6.
78. Chopra A. Al in supply \& procurement. Amity International Conference on Artificial Intelligence (AICAI) 2019; 308-316.

79. Mahanta NR, Rajput B. Landscape interventions for resilience and sustainability in urban wetland parks: a review. Advances in Science and Engineering Technology International Conferences (ASET) 2019; 1-6.

80. Chopra A. Technology in procurement and supply as prevalent today and scope for future. International Conference on Automation and Computational Engineering (ICACE) 2018; 216-223. 